Ks. Janusz Królikowski

Uniwersytet Papieski Jana Pawła II w Krakowie

\title{
SOBÓR TRYDENCKI I JEGO INSPIRUJĄCE ZNACZENIE
}

Podejmowane wysiłki eklezjalne związane z prowadzeniem synodów, których domaga się także II Sobór Watykański, zawsze mogą czerpać inspirację z dziejów tych ważnych wydarzeń i instytucji eklezjalnych, którymi są sobory powszechne oraz synody partykularne odbywane w różnych czasach i w różnych miejscach. Nie przypadkiem cieszą się one rosnącym zainteresowaniem badaczy dziejów Kościoła, którzy za pośrednictwem prowadzonych analiz przyczyniają się do wielkiego dzieła odnowy Kościoła postulowanej przez II Sobór Watykański, wskazujący zarazem, że synody powinny odgrywać w tym ważnym i zawsze pilnym dziele przodującą rolę. Od 1969 roku ukazuje się przegląd „Annuarium Historiae Conciliorum” oraz wydaje się w nowych opracowaniach dokumenty soborów powszechnych i synodów partykularnych. Doczekaliśmy się także pełnego polskiego wydania dokumentów soborów powszechnych wraz z thumaczeniami wszystkich ich orzeczen ${ }^{1}$. Została zrobiona w tej materii wielka praca, z której warto korzystać w teologii i duszpasterstwie, mając na względzie służbę Kościołowi.

W tym miejscu zamierzamy zwrócić uwagę na Sobór Trydencki, mając przede wszystkim na uwadze wydobycie jego specyfiki, która może być inspirująca także dzisiaj, gdy prowadzi się rozmaite synody². Doświadczenia

1 Por. Dokumenty Soborów Powszechnych, t. 1-4, układ i oprac. A. Baron, H. Pietras, Kraków 2001-2004.

2 Na temat Soboru Trydenckiego fundamentalnym dziełem na długo pozostanie: H. Jedin, Geschichte des Konzils von Trient, t. 1-5, Darmstadt 2017. Por. także J. W. O’Malley, Trydent. Co się zdarzyło podczas soboru, tłum. M. Chojnacki, Kraków 2014. 
historyczne, swoiste magisterium historiae, zawsze mogą stać się lekcją dla naszych poszukiwań, które chociaż mają miejsce w zmienionych okolicznościach, zawsze pozostają w ciągłości z tym, co minione. Weryfikuje się to w szczególny sposób w życiu i misji Kościoła, którego kluczowym elementem jest jego „pamięć”, zakorzeniona w traditio Christi, wyrażająca się w kulcie, nauczaniu i obyczaju, która zachowuje swoją żywotność w każdym czasie, pozwalając nawiązać osobistą i zbawczą więź z Chrystusem, pozostącym „wczoraj i dziś, ten sam także na wieki” (Hbr 13, 8). Analiza historyczna prowadzona w duchu teologicznym wyrasta $\mathrm{z}$ tej tradycji, stając się jej żywą kontynuacją. Podstawowe znaczenie tego faktu wydobył już św. Tomasz z Akwinu, gdy stwierdzał: „Zmiana czasów nie dokonuje zmian w wierze, ale ją determinuje” (Variatio temporis determinant, non variat fidei) ${ }^{3}$. Uwzględnienie, w jaki sposób w przeszłości rozumiano zachodzące zmiany, mając na uwadze zachowanie integralności wiary, pozostaje ważną lekcją eklezjalną, której nie można bagatelizować w naszych aktualnych poszukiwaniach teologicznych i eklezjalnych.

\section{Znaczenie soborów powszechnych}

Analizując dzieje dwudziestu jeden soborów powszechnych, można dość łatwo stwierdzić, że tylko trzy z nich mogą równać się z Soborem Trydenckim, jeśli chodzi o ich znaczenie dla życia Kościoła ${ }^{4}$. Są to: I Sobór Nicejski, Chalcedoński i II Watykański. Pierwszy z nich zdefiniował wiarę chrystologiczną i ukierunkował tym samym doktrynę trynitarną, wprowadzając do języka kościelnego kluczowe pojęcie homoousios, które może być uznane za „pradogmat” chrześcijański. Drugi sobór sprecyzował znaczenie tego pojęcia, a w ten sposób zostały odrzucone błędne interpretacje dotyczące jednej osoby oraz natur boskiej i ludzkiej w Jezusie Chrystusie. Nauczanie obydwu soborów stało się przedmiotem żywiołowych dyskusji. Trzeba było niemal pół wieku, aby została utrwalona doktryna nicejska dotycząca rozumienia homoousios oraz jego właściwe znaczenie soteriologiczne. Niemal dwa wieki były potrzebne, aby

3 Tomasz z Akwinu, In III Sententiarum, d. 24 a. 1 q. 3 c.

${ }_{4}$ Por. M. Starowieyski, Sobory Kościoła niepodzielonego, cz. 1: Dzieje, Tarnów 1994; J. Dyl, Sobory powszechne w drugim tysiącleciu chrześcijaństwa, Tarnów 1997; K. Schatz, Sobory powszechne - punkty zwrotne w historii Kościoła, thum. J. Zakrzewski, Kraków 2001. 
została w pełni przyjęta doktryna dotycząca dwóch natur w Jezusie Chrystusie. W obydwu przypadkach zatryumfowała ostatecznie prawdziwa wiara - do dzisiaj trynitarna i chrystologiczna nauka Kościoła opiera się na zastosowanych wówczas pojęciach i na wypracowanych formułach. Jest to doktryna, którą wyznali ojcowie II Soboru Watykańskiego i na której zbudowali swój wykład doktrynalno-pastoralny dotyczący tajemnicy i misji Kościoła. Na początku każdej sesji soborowej wyznawali oni wiarę sformułowaną w Credo nicejsko-konstantynopolitańskim. Nie stosowali oni trydenckiego wyznania wiary (Professio fidei tridentina), które po zakończeniu Soboru Trydenckiego polecił ułożyć papież Pius IV na podstawie wydanych przez niego orzeczeń, co bynajmniej nie oznaczało pomniejszenia Soboru Trydenckiego i jego nauczania.

Sobór Trydencki został zwołany w celu przezwyciężenia trudności wewnętrznych i zewnętrznych, które dotknęły Kościół. Był on odpowiedzią na rozbicie wiary na Zachodzie, co wyraziło się w podwójny sposób. Po pierwsze sobór miał określić wiarę katolicką w relacji do nauczania przedstawionego przez protestantów, wskazując jednoznacznie na to, co jest, a co nie jest katolickie. W oparciu o to zaktualizowane określenie doktryny - po drugie - miała się zacząć wewnętrzna odnowa Kościoła, właśnie ta odnowa, na której potrzebę wskazywał Luter i jego zwolennicy, uznając, że może ona nastąpić tylko przez odnowienie papiestwa i przez powrót do ,czystej nauki Ewangelii”. Takie były dwa wiodące zadania, które papież Paweł III wyznaczył Soborowi Trydenckiemu w bulli Laetare Jerusalem zwołującej sobór (19 listopada 1544)5.

Czy Sobór Trydencki spełnił pokładane w nim duże nadzieje? Tylko wsłuchując się w głos i imperatywy epoki, sobór mógł wpłynąć na życie Kościoła. Jeśli by tego nie uczynił lub uczynił to tylko połowicznie, miałby niewielki wpływ na Kościół. Byłaby to raczej klęska soboru. Dzieje Kościoła i soborów znają takie porażki, niekiedy naznaczone także głęboko negatywnymi konsekwencjami. Asystencja Ducha Świętego, którą Kościół łaskawie otrzymał od swego Założyciela, gwarantuje, że w dziedzinie wiary nie wpada on w błąd, ale ta asystencja nie gwarantuje - na odwrót - że to, co konieczne lub odpowiednie, zostanie zawsze uczynione we właściwym czasie, we właściwy sposób i we właściwym miejscu. Czynnik ludzki jest bardzo mocno obecny w urzeczywistnianiu się Kościoła.

${ }^{5}$ Por. B. Kumor, Historia Kościoła, t. 5: Czasy nowożytne. Rozłam w chrześcijaństwie zachodnim, Lublin 2002, s. 161-163. 


\title{
Sprecyzowanie wiary katolickiej
}

Historia potwierdza, że Sobór Trydencki nie był porażką, nawet jeśli nie wszystkie jego wskazania zostały w pełni zrozumiane i zrealizowane. Przez cztery stulecia kształtował on w sposób bardzo wyraźny życie Kościoła swoimi dekretami dogmatycznymi, które zachowują swoją wagę doktrynalną i pozostają zobowiązujące, oraz swoimi dekretami reformacyjnymi, które przechodząc proces weryfikacji praktycznej i stopniowego dojrzewania, stały się podstawą prawa kanonicznego. Życie kościelne było bezpośrednio kształtowane za ich pośrednictwem aż do początku XIX wieku, który postawił przed Kościołem całkowicie nowe wyzwania - udzielenie odpowiedzi na nie zostało podjęte przez dwa Sobory Watykańskie. Dekrety dogmatyczne o Piśmie Świętym i Tradycji jako źródłach objawienia, o grzechu pierworodnym i o usprawiedliwieniu, o siedmiu sakramentach, o ofierze mszy świętej i o czci świętych wyznaczają ścisłą linię podziału między doktryną katolicką i protestancką. Potępiają one w dołączonych kanonach błędy, przy czym nie wymieniają ich autorów. W części dogmatycznej sformułowanej pozytywnie wyznaczają one kierunek wykładu wiary, którym powinni kierować się teologowie, kaznodzieje i katecheci. Ta część nauczania soborowego stanowiła nowość w porównaniu z poprzednimi soborami - nowość, która była zgodna z postulatami ówczesnej epoki. Zdano sobie jasno sprawę, że nie wystarczy potępiać błędy, ale nade wszystko konieczny jest pozytywny i po ludzku przychylny wykład prawd wiary. II Sobór Watykański poszedł tą samą drogą, ponieważ papież św. Jan XXIII, dokonując otwarcia obrad soborowych, wyznaczył mu bardzo jasny program:

\begin{abstract}
Kościół zawsze przeciwstawiał się błędom; często także z największą surowością je potępiał. Teraz jednak Oblubienica Chrystusa woli raczej użyć lekarstwa miłosierdzia niż surowości. Pragnie ona wyjść naprzeciw potrzebom współczesności ukazując raczej moc swej doktryny niż odnawiając potępienia. Nie dlatego, żeby brakowało błędnych nauk, niebezpiecznych opinii i idei, których trzeba się strzec i które trzeba przezwyciężyć, lecz sprzeciwiają się one tak wyraźnie prostej normie uczciwości i wydały tak zgubne owoce, że wydaje się, iż sami ludzie są gotowi je potępić 6 .
\end{abstract}

6 Jan XXIII, przemówienie Gaudet Mater Ecclesia, 11.10.1962, [w:] A. Michalik, Odkryć sobór. Szkic historyczno-teologiczny Soboru Watykańskiego II, Tarnów 2006, s. 127. 
W Trydencie nie można było uniknąć potępienia błędów - biorąc pod uwagę ówczesną sytuację eklezjalną, było ono po prostu absolutnie konieczne. Kontrowersje doktrynalne nie tylko dotyczyły - jak uważał na przykład Erazm z Rotterdamu, a za nim wielu innych - sprzecznych poglądów między teologami, ale uderzały one w samą istotę wiary katolickiej. Łatwe pogodzenie rozmaitych poglądów nie było wówczas możliwe. Oczywiście Sobór Trydencki nie był soborem „,zjednoczeniowym”, jak niektóre sobory średniowieczne, ale nie był też tylko soborem „rozdzielającym”. Nie spowodował on podziału w Kościele, ponieważ taki podział był już faktem, gdy sobór był zwoływany i gdy się zbierał. Dokonał on jedynie - temu nie można zaprzeczać - zaakcentowania istniejącego już podziału. Sobór Trydencki zapoczątkował więc w Kościele tak zwaną ,epokę konfesyjną”, czego najbardziej wymownym wyrazem stały się „teologie konfesyjne”.

W wypowiedziach doktrynalnych Soboru Trydenckiego można zauważyć zaskakujące opuszczenie. Od samego początku w nurtach reformacyjnych został mocno zaatakowany prymat papieski i była konsekwentnie kontestowana nieomylna władza dogmatyczna Kościoła. Mimo to Sobór Trydencki nie ogłosił odrębnego dokumentu, który byłby odpowiedzią na ten aspekt kontestacji reformacyjnej. Oczywiście w dekretach poświęconych sakramentom, szczególnie w dekrecie o sakramencie święceń, określił on pewne elementy struktury Kościoła i uwypuklił jego charakter hierarchiczny, ale nie wypracował jakiejś własnej eklezjologii. Eklezjologia trydencka zasługuje jednak na uwage i na szerszą analizę ${ }^{7}$. Eklezjologia nie była jeszcze wystarczająco dojrzała, jak jasno pokazują debaty prowadzone w trzecim okresie Soboru Trydenckiego (1562-1563). Te wątki, które zostały pominięte na Soborze Trydenckim, zostały potem podjęte przez Sobory Watykańskie, opierając się na osiągniętej dojrzałości teologicznej kluczowych kwestii dotyczących Kościoła.

\section{Reforma katolicka}

Określenie wiary katolickiej w dekretach dogmatycznych pozostałoby bezowocne, gdyby nie została podjęta wewnętrzna reforma życia Kościoła, to znaczy radykalna reforma nie tylko obyczajów, lecz także duszpasterstwa.

7 Por. J. Rigal, L'ecclésiologie tridentine, „Bulletin de Littérature Ecclésiastique” 91 (1990), s. 251-273. 
Nadużycia były czymś więcej niż tylko głębszą okazją do reakcji ze strony reformatorów i ich apostazji. Wielu współczesnych, jak na przykład cesarz Karol V Habsburg8, było zdania, że ruch apostazji straciłby swoją przyciągającą siłę, gdyby Kościół wyeliminował nadużycia bezdyskusyjnie obecne w jego łonie. Przedstawiciele takiego poglądu uważali reformę obyczajów za pierwszorzędne zadanie soboru, o wiele pilniejsze niż określenie doktryny. W czasie pierwszej sesji soborowej, 13 grudnia 1545 roku, zostało ojcom soborowym zadane pytanie, które określa i wskazuje właściwy przedmiot debaty soborowej:

Wielebni i czcigodni Ojcowie! Czy zgadzacie się, aby postanowić i ogłosić, że na cześć i chwałę świętej i niepodzielnej Trójcy, Ojca i Syna, i Ducha Świętego, rozpoczyna się i podejmuje obrady święty i generalny Sobór trydencki, dla wzrostu i wywyższenia wiary oraz religii chrześcijańskiej, wykorzenienia herezji, pokoju i jedności Kościoła, odnowy duchowieństwa i ludu chrześcijańskiego, poskromienia i zniszczenia wrogów imienia chrześcijańskiego? Wówczas wszyscy jednomyślnie odpowiedzieli: Zgadzam się9 .

W punkcie wyjścia uznano więc, że dwa zadania wyznaczone przez papieża posiadały taką samą rangę i zdecydowano o ich równoległym traktowaniu. Nie można jednak negować, że zagadnienia dotyczące reformy w dwóch okresach: 1545-1547 i 1551-1552, były podejmowane w niewielkim stopniu. Tylko dalekowzroczność i zdolności taktyczne, które zaprezentował kardynał Giovanni Gerolamo Morone ${ }^{10}$, sprawiły, że stało się możliwe na sesjach XXIII-XXV w 1563 roku zatwierdzenie dekretów o obowiązku rezydencji biskupów w ich diecezjach, o zakładaniu seminariów biskupich, o regularnym zwoływaniu synodów prowincjalnych i diecezjalnych, o reformie zakonów, o zawarciu małżeństwa secundum formam tridentinam. $\mathrm{W}$ ten sposób nastąpiło zdecydowane wyjście naprzeciw pragnieniom refor-

8 Por. A. Kohler, Karl V. 1500-1558. Eine Biographie, München 2001.

9 Sobór Trydencki, Dekret o rozpoczęciu soboru, [w:] Dokumenty Soborów Powszechnych, t. 4: 1511-1870. Lateran V, Trydent, Watykan I, układ i oprac. A. Baron, H. Pietras, Kraków 2004, s. 197.

${ }^{10}$ Por. M. Firpo, Inquisizione romana e controriforma. Studi sul cardinal Giovanni Morone (1509-1580) e il suo processo d'eresia, Brescia 2005; L'uomo del Concilio. Il cardinale Giovanni Morone tra Roma e Trento nell'età di Michelangelo, a cura di R. Pancheri, D. Primerano, Trento 2009. 
my przedstawionym $\mathrm{w}$ memoriałach przedłożonych przez grupy biskupów hiszpańskich, francuskich, reprezentantów cesarza, a także przez biskupów włoskich.

Głównie dzięki temu dziełu reformistycznemu, nad którym pracował kardynał Morone, a do którego wydatnie przyczynił się także kardynał Gabriele Paleotti, arcybiskup Bolonii ${ }^{11}$, Sobór Trydencki stał się soborem reformującym, a tym samym mógł wyznaczyć początek nowej epoki w życiu Kościoła, wyraźnie i konsekwentnie, a nawet profetycznie kształtując jego misję w kolejnych, niełatwych wiekach. Epoka ta zasługuje na miano „reformy katolickiej”, a nie tylko „kontrreformacji”, jak na ogół się ją określa ${ }^{12}$.

Na czym polega skuteczność Soboru Trydenckiego i wpływ, który stał się możliwy dzięki jego nauczaniu i dzięki sformułowanym wskazaniom duszpasterskim? Wszystko wskazuje na to, że wynika on z tego, że w Trydencie zasłuchano się uważnie w wezwania epoki (dzisiaj powiedzielibyśmy o „znakach czasu"), starając się twórczo odpowiedzieć na jej potrzeby, szukając nowych miar teologiczno-duszpasterskich istniejących zjawisk oraz proponując nowe rozwiązania, na przykład seminaria. To, co nowe, zostało organicznie połączone $\mathrm{z}$ tym, co stare - z żywą Tradycją kościelną. Nie nastąpiło jakieś zerwanie w życiu Kościoła, ale postawiono na ewolucję wymaganą przez nowe czasy. Podstawowa koncepcja reformy trydenckiej była więc skoncentrowana na zasadzie: salus animarum suprema lex.

Decydujące dla przebiegu reformy katolickiej wyznaczonej przez Sobór Trydencki było to, że papiestwo uczyniło z niej swój właściwy program działania. Wynikało to nie tylko z tej racji, że papież Paweł IV, mimo sprzeciwu pewnych kręgów kurialnych, zatwierdził jednoznacznie i bez wyjątku rozporządzenia zredagowane pod przewodnictwem legatów papieskich, a także dlatego że jego następca - Pius V uzupełnił je zgodnie z oczekiwaniem soboru (papieska reforma brewiarza i mszału). Jeszcze ważniejsze było to, że papieże końca XVI wieku, jakkolwiek bardzo różnili się osobowościami, wystarczy pomyśleć o Grzegorzu XIII i Sykstusie V, zgodnie zaangażowali się w realizację postanowień soborowych i w utworzenie w tym celu nowego organu kurii

\footnotetext{
${ }^{11}$ Por. P. Prodi, Il cardinale Gabriele Paleotti (1522-1597), t. 1-2, Roma 1959-1967.

${ }^{12}$ Por. H. Jedin, Katholische Reformation oder Gegenreformation? Ein Versuch zur Klärung der Negriffe nebst einer Jubiläumsbetrachtung über das Triener Konzil, Luzern 1946.
} 
rzymskiej, którym stała się Sacra Congregatio Concilii (1564), mająca czuwać nad wprowadzeniem postanowień soboru w życie ${ }^{13}$.

Relacjonując w 1586 roku dokonującą się odnowę Kościoła w duchu Soboru Trydenckiego, Lorenzo Priuli, ambasador Republiki Weneckiej przy Stolicy Apostolskiej, późniejszy patriarcha Wenecji i kardynał, pisał: „Wydaje się, że Pan Bóg rzeczywiście otworzył oko swej przychylności w stosunku do Kościoła, dając mu po soborze jednego po drugim trzech papieży, którzy byli jego dobrymi sługami"'14. Faktycznie, bez energii i determinacji wykazanej papieży Piusa V (1566-1572), Grzegorza XIII (1572-1585) i Sykstusa V (1585-1590) trydenckie dekrety reformacyjne pozostałyby martwą kartą.

\section{Osąd historii}

Paolo Sarpi (1552-1623) 15 w swojej zdecydowanej krytyce soboru zaprezentowanej w słynnej pracy Istoria del Concilio tridentino, szybko umieszczonej na Indeksie, skoncentrował się na omówionym wyżej jego aspekcie $^{16}$. Postawił on jako zasadnicze pytanie, dlaczego papiestwo utożsamiło się z Soborem Trydenckim? W udzielonej odpowiedzi podkreślił, że chodziło o umocnienie za jego pośrednictwem swojego panowania nad narodami. Sarpi nie widział w soborze niczego innego, jak tylko subtelną intrygę kurii rzymskiej, usiłującej panować nad światem. Według niego reforma trydencka nie była reformatio Kościoła, ale w najwyższym stopniu stała się jego deformatio.

Jezuicki historyk Sforza Pallavicino (1607-1667) ${ }^{17}$, późniejszy kardynał, odwołując się do bogatszych i pewniejszych źródeł, zdecydowanie odrzucił tezę

${ }^{13}$ Por. F. M. Capello, Sacra Congregazione del Concilio, [w:] Enciclopedia cattolica, t. 4, Città del Vaticano 1950, kol. 321-323.

${ }^{14}$ E. Albèri, Relazioni degli ambasciatori veneti al Senato, series 1a, t. 4, Firenze 1863, s. 305.

${ }^{15}$ Por. G. Getto, Paolo Sarpi, Firenze 1967; C. Pin, Ripensando Paolo Sarpi, Venezia 2006.

${ }^{16}$ Por. P. Sarpi, Istoria del Concilio tridentino, nella quale si scoprono tutti gli artifici dla corte di Roma, Geneua 1629. Praca ukazała się w Londynie w 1619 roku, a autor ukrył się pod pseudonimem: Pietro Soave Pollano.

${ }^{17}$ Por. S. Appolonio, Sul nome del Padre (non Pietro) Sforza Pallavicino, „Studi Seicenteschi" 54 (2013), s. 335-341. 
Sarpiego $^{18}$. Najbardziej jednak zdecydowanego odrzucenia tej tezy dokonały same dzieje Kościoła. Po Soborze Trydenckim i w oparciu o jego zbawienne nauczanie Kościół wyraźnie odrodził się pod koniec XVI i w XVII wieku, wydał wielkich świętych, wielkich duszpasterzy, wielkich mistrzów życia duchowego i wielkich teologów. Sztuka kościelna we wszystkich swoich dziedzinach (architektura, malarstwo, rzeźba, muzyka itd.) otrzymała wielki impuls ze strony odnawiającego się i umacniającego życia religijnego, tworząc właściwie ostatni monumentalny styl, którym stał się barok. Miasto Rzym, będące siedzibą papiestwa, odkryło wielkość swoich męczenników (katakumby) i swoje znaczenie religijne, nadając mu nowy splendor i zyskując nowe pierwszeństwo w świecie. Przez swoje nauczanie i tworzenie kolegiów narodowych Rzym stał się centrum duchowym i intelektualnym w sensie o wiele głębszym, niż był nim w średniowieczu.

Mimo tych niewątpliwych osiągnięć, dostrzeganych już przez bezpośrednich świadków dokonującej się recepcji, Sobór Trydencki w XVII i XVIII wieku był znakiem sprzeciwu nie tylko dla świata protestanckiego, lecz także dla gallikanów i febronianów. Dopiero w XIX wieku został on uwolniony od nacisku negatywnych osądów i zaczął jeszcze pełniej rzucać swoje łagodne, ale wyjątkowo przenikliwe światło na obecność Kościoła w świecie i na jego stopniowe urzeczywistnianie się w dziejach. Dopiero pod koniec XIX wieku, po I Soborze Watykańskim, zaczął się nowy spór o Sobór Trydencki, wywołany pracami Augustina Theinera (1804-1874) ${ }^{19}$ i Ignaza von Döllingera $(1799-1890)^{20}$.

Papież Leon XIII podjął wyzwanie i udostępnił do badań naukowych dokumenty z Tajnego Archiwum Watykańskiego zebrane w zespole „Concilium”21, przede wszystkim zaś „akta” sekretarza soboru, którym był biskup Angelo Massarelli (1510-1566), zawierające skrupulatnie prowadzony diariusz prac soborowych zatytułowany Acta genuina ss. oecumenici Concilii tridentini.

\footnotetext{
${ }^{18}$ Por. S. Pallavicino, Istoria del concilio di Trento, cz. 1-2, Roma 1656-1657.

${ }^{19}$ Por. H. Jedin, Augustin Theiner, „Archiv für schlesische Kirchengeschichte” 31 (1973), s. 134-176; H. H. Schwedt, Theiner Augustin, [w]: Lexikon für Theologie und Kirche, t. 9, Freiburg-Basel-Wien 2006, kol. 1387-1388.

${ }^{20}$ Por. V. Consemius, Döllinger, [w:] Lexikon für Theologie und Kirche, t. 4, Freiburg-Basel-Wien 2006, kol. 306-307.

${ }^{21}$ Por. G. Martina, L'apertura dell'Archivio Vaticano, ,Archivum Historiae Pontificiae" 19 (1981), s. 239-307.
} 
Friedrich Denifle (1844-1905)22 wydatnie przyczynił się do podjęcia ważnej decyzji o opublikowaniu akt Soboru Trydenckiego przez Goerres-Gesellschaft. W 1901 roku pojawił się pierwszy tom liczący ponad tysiąc stron, zawierający także diariusz Massarellego. Dzisiaj mamy do dyspozycji monumentalne, wielotomowe wydanie dokumentacji soborowej, którą zawdzięczany wydawnictwu Herder we Fryburgu Conciulium Tridentinum. Diariorum, actorum, epistularum, tractatuum nova collectio (1964-2001).

Obawa przed ujawnieniem dokumentów, którą przezwyciężył papież Leon XIII, okazała się nieuzasadniona. Dzięki jego decyzji możemy dzisiaj patrzeć na Sobór Trydencki w taki sam sposób, w jaki patrzymy na każdy inny sobór, w tym także po ludzku. Spierano się na nim i dochodziły do głosu różne poglądy, spierano się o prawdę i o kształt Kościoła, aby był możliwie najbardziej zgodny z zamysłem Bożym. Czy mogło być inaczej? Asystencja Ducha Świętego, którą cieszą się sobory powszechne, nie wyklucza wysiłku podejmowanego przez ludzi, ale go zwyczajnie zakłada; ta sama asystencja interweniuje pozytywnie, aby podejmowana praca była jak najbardziej owocna oraz skuteczna w życiu Kościoła i w pełnionej przez niego misji.

Z pomocą źródeł historycznych, z perspektywy niemal pięciu wieków i w świetle kolejnych soborów: I i II Watykańskiego, jesteśmy w stanie określić miejsce Soboru Trydenckiego w dziejach Kościoła Chrystusowego. Był on niewątpliwie wydarzeniem i instytucją, dzięki któremu sam Chrystus wyprowadził swój Kościół z jednego z najpoważniejszych kryzysów w jego dziejach, dostarczył mu pewności w wierze i pokazał sposoby podjęcia autentycznej troski o dusze, zdecydowanie odpowiadającej duchowi i potrzebom czasów. Taki jest cel wszystkich soborów powszechnych, zarówno starożytnych, jak i nowożytnych, taki był też cel - o czym warto szczególnie pamiętać - II Soboru Watykańskiego. Taki jest również cel synodów partykularnych, które wzorują się, a powinny to czynić coraz wydatniej, na soborach powszechnych. Lekcja zostawiona przez Sobór Trydencki zasługuje w takim przedsięwzięciu eklezjalnym, jakim jest synod partykularny, także na uwagę i na podjęcie wysiłku odczytania jego lekcji.

${ }^{22}$ Por. J. Köhler, Denifle, Heinrich Suso, [w:] Theologische Realenzyklopädie, t. 8, 1981, s. 490-493. 